\title{
An intellectual plein air: a walk through the Rozanov places of Yelets
}

\author{
Aleksandr V. Skiperskikh ${ }^{1 *}$ \\ ${ }^{1}$ Bunin Yelets State University, Philosophy and Social Science Department, Yelets, Russia
}

\begin{abstract}
This paper is an original reconstruction of the Yelets text of the Russian religious philosopher Vasily Rozanov. The author draws up a map of Rozanov's addresses in Yelets and conducts an intellectual plein air over them, inviting students to it. During an intellectual walk along provincial Yelets, an attempt is made to reconstruct Rozanov's Yelets routes. Each place, marked during the plein air could be described by Rozanov in his texts. This form of academic dialogue is held for the first time and can serve as an alternative to traditional classroom forms of communication. The author sees the intellectual plein air as an attempt to capture and describe the images of the departing Yelets in the way the Russian philosopher might have seen it. Any timely fixation of the memory of Rozanov today turns out to be the correct tactical decision. The current Yelets is gradually giving in to the impulses of modernization. In addition to the intellectual temptations of new readings of Rozanov's texts in the framework of this plein air, this form of academic dialogue, taken outside the framework of the university audience, solves another problem. The author considers new aesthetic horizons of the familiar ethnic landscape. Yelets expands anew, containing the memory of an outstanding representative of Russian culture, and becomes a part of world culture.
\end{abstract}

Keywords: Yelets, intellectuals, province, Vasily Rozanov.

\section{Introduction}

The Russian province retains a unique cultural potential. It is too speculative to represent the images of Russia, its past, present, and future only in large cities, the centers of the empire. It is equally impossible to see modern Russia through the prism of the capital's prosperity, because, as Georgy Gachev once noted, "St. Petersburg is not Russia" [1: 388].

Many representatives of Russian culture grew up in the provinces, creating a special intellectual tension there. Their work can be viewed in the context of the cultural memory of a particular place. In the Lipetsk region today one can see partial practices of the commemoration of famous secular and religious intellectuals, prompting discussions about their texts in the scientific community [2]. The region celebrated the 150th anniversary of I. Bunin, slightly overshadowed by COVID-19, with special attention. The teaching experience of the Russian religious philosopher Vasily Rozanov (1856-1919) is connected with Yelets, too. In 1887, he arrived in Yelets from Bryansk. Rozanov, already having a

\footnotetext{
*Corresponding author: pisatels@mail.ru
} 
proper intellectual background by that time, became a history and geography teacher in the Yelets grammar school.

\section{Methods}

The memory of Rozanov is becoming established in Yelets, and city intellectuals, local historians, and representatives of city authorities often appeal to it. However, such figures remain at the level of demagoguery. The reality turns out to be tougher. Today, modernization processes are underway in Yelets; the infrastructure is being modified. There are risks that Rozanov's chronotopes will no longer be preserved in the form in which they were noted in his enigmatic texts.

The memory of Rozanov in Yelets is structured by various actors. These are the authorities using the name of the philosopher in presentation texts about Yelets, educational institutions (Yelets State University named after I.A. Bunin, Secondary School No. 1 named after M.M. Prishvin, etc.), and a private initiative of local gallery owners and local historians ${ }^{\dagger}$. Such stories of working with memory actualize the need to use the structural method.

The method we use for our reconstruction of Rozanov's Yelets space involves a walk through some chronotopes associated with his stay in Yelets. Rozanov's places in Yelets are reflected in his texts. The intellectual mission is defined in its ability to broadcast knowledge and, as noted by J. Le Goff, "to wedge into the world of the spirit" [3: 5]. That is why our walks along Rozanov's Yelets are held together with the students. The visual experience of comprehending Rozanov's intellectual biography can become a completely atmospheric form of educational practice. "I have always been an observer in the world, not a participant. Hence such longing", the philosopher once admits in "Fallen Leaves" [4: 159].

The risks of modernizing urban space urge us to want to remember what has not yet completely disappeared. It is important to be able to capture what has not yet been modernized, what still looks more or less authentic. The Rozanov plein air can be viewed in the context of memory studies.

\section{Results}

The active development of the urban space in the interests of the new political elite of the city presupposes an urban reboot of the city center. It constantly attracts teams of fashion designers and architects, the Art. Lebedev Studio, etc. However, in Yelets, there are still addresses that could have been visited by the Russian philosopher and remain unchanged to this day. There are still several addresses that can be reconstructed as Rozanov's chronotopes.

Address 1. Rozanov taught at the Yelets classical grammar school for boys from 1887 to 1891. The school building has survived and preserved its function. Today there is Secondary School No. 1 named after M.M. Prishvin (Sovetskaya Street, 121). The memory of Rozanov's teaching practice, which, probably, could be appreciated to a greater extent by his most famous student, M. Prishvin, who had experienced his kind of "trolling" [5: 13], is recorded in a memorial plaque installed on the school building in May 2006.

\footnotetext{
${ }^{\dagger}$ In the early 1990s, a republican conference dedicated to the memory of V. Rozanov was held in Yelets. Some university scholars, up until today, are well-known researchers of Rozanov's heritage. At the entrance to the library of the Yelets State University named after I.A. Bunin one can see a bust of the Russian philosopher. In the late 1990s, we had to participate in an international conference in Nizhny Novgorod. One professor was then extremely surprised by the fact that we had come from Yelets because the clearest association he had with the city was the period of Rozanov's life in it.
} 
Address 2. Unlike the former building of the Yelets classical grammar school for boys, the situation is much more complicated with the current territory of the Children's Park, the former Kalabinsky women's shelter. In the Church of the Holy Trinity, which was located in a two-story building in the courtyard of the orphanage in May 1891, Rozanov secretly married Varvara Butyagina. After that Rozanov was forced to leave Yelets. The building of the temple was demolished back in the 1920s. Lipetsk local historians confirm this, saying that at that place of the Trinity Church today, "there is a flowerbed between two former wings of the Kalabinskaya estate on the right at the entrance to the Children's Park" [6:355]. The Children's Park underwent reconstruction not so long ago, as a result of which its layout changed. However, this important address can still be identified. The wing and gates of the shelter have been preserved. After the restoration, the forged park fence, as Rozanov could see it, returned to its place.

Address 3. In Yelets, the addresses of Rozanov's direct residence are still preserved. This is the address in the house of Pelageya Rogacheva near the Valuisky Bridge (the modern Mayakovsky Street, 54). In this house near the Yelchik River in 1887 - the 1890s, V. Rozanov rented an apartment at a boarding house [7]. This place was traditionally populated by burghers and artisans. The famous tanneries of the Black Sloboda were located here, following the "chain along the Yelchik River" [8: 137]. Although Rogacheva's house was not preserved the way the philosopher could see it, this chronotope can be the most successful for the intellectual plein air.

Address 4. Another Rozanov's well-known address in Yelets is the Rudnevs' house (Profsoyuznaya Street, 12). This was the address of Rozanov's future wife, V. Butyagina, who was distantly related to Archbishop Innocent of Kherson. Local historians have practically no doubts about the accuracy of the definition of this address, which was mentioned by Rozanov himself as "a house opposite the Presentation Church" [4: 388]. As in the case of the Rogacheva house, this chronotope reveals Yelets architecture in an atmospheric way. Near the Rudnevs' house, there is one of the oldest city churches, the Presentation (Vvedenskaya) Church, next to which the philosopher often took walks.

Address 5. This address, possibly related to Rozanov's Yelets text, is related to his high school conflict with M. Prishvin. This is one of the once prominent Yelets shops located on the most prominent street of the city. It was in the store of Chernomashentsev, located in Popov's house (Mira Street, 119), where Prishvin bought the necessary equipment to escape to America with other grammar school students. Rozanov might have started paying more attention to the stock of that particular store after a quarrel with the impudent school student. Returning to the Yelets story in the famous cycle "Mortal Things" (1913), he mentions how he told his future wife about the problems that lay in wait for him, without mentioning Prishvin's name: "In Yelets, there was something that threatened me, and among other words, I told her that I would buy a revolver" [9: 137].

Rozanov could have had the most serious reasons for concern. Cases, when school threats could be brought to life, could be quite frequent. At the school itself, in January 1885, the headmaster's office investigated the case of Pyotr Vakulin, a schoolboy who brought a revolver with him and who accidentally wounded one of the school students [10: 80].

Address 6. As already noted, the memory of Rozanov in Yelets is supported not only "from above", representing the efforts of official institutions, but also "from below", within the framework of private cultural initiatives. Since Rozanov's life in Yelets could be associated with a rather influential and well-known family of the priest in the city, the rector of the Vladimir Church in the Black Sloboda, the local history archives can be of great importance for the subsequent commemoration. The memory of Rozanov becomes nonpublic, secluded, belonging to a private initiative.

The monument to Rozanov in the courtyard of the Cultural Center named after V.S. Sorokin (Sovetskaya Street, 56) can be an example of that. The monument was made 
by E. Krikunov, a gallery owner in Yelets, at his own expense. Today the monument is closed from direct access and can only be seen upon request. Hence, it is no coincidence that the monument can be interesting for those who purposefully come to the city. As Krikunov himself notes, "he offered the city authorities to erect a monument somewhere in the city, but they refused. Then he put it "in his courtyard"' [11]. In such a revelation, one can see common symptoms for Russia, when the bureaucratic pressure described by some researchers [12], most likely, penetrates cultural discourse. The secluded life of the philosopher himself seems to be projected onto the practice of working with his memory, drawing them inward, into itself.

\section{Discussion}

The mentioned addresses are by no means a complete list of Rozanov's places in Yelets. By full right, the City Garden, the Monastery on the outskirts of Yelets in the direction of Orel, the Vladimir Church in the Black Sloboda, the Chernoslobodskoe cemetery, etc. can be added to them. We did not try to maximize the identification of Rozanov's addresses. More important for us was the actual availability of those addresses that were covered in the intellectual plein air.

Let us note a certain ambiguity in the policy of the city authorities. On the one hand, the importance of Rozanov's figure today can be understood by the new urban elite, realizing its importance in the policy of filling the urban cultural vacuum. Thus, the mayor of Yelets E. Borovskikh came to the evening show of the film "Boys" (1990) based on one of the chapters of "The Brothers Karamazov" by F. Dostoevsky. The film contains Rozanov's mythologemes, as the very fact of Rozanov's appearance in Yelets is associated with Dostoevsky. The viewing was held outdoors in a fairly entourage courtyard of the former county court. On the other hand, today the urban authorities are busy with more trivial problems of life support, which postpones the issue of commemorating Rozanov for an indefinite period. The practices that have already recorded his traces on the Yelets land were made before the legitimization of the current political elite.

Rozanov's potential is huge, and with due attention, it can become an additional motive for the cultural attractiveness of the city. "The understanding of Vasily Rozanov is somewhere far ahead," noted the prominent Soviet intellectual V. Turbin, who sympathized with Yelets [13: 130]. In the event of a new turn towards the Russian province and littlestudied figures, Yelets can acquire another attractive facet and sparkle with a new charm. The found form of communication with students solves the problem of preserving the intellectual field around the figure of an outstanding Russian religious philosopher and his connection with Yelets.

\section{Conclusion}

The intellectual plein air allows us to re-evaluate the dialectics of Yelets life, which was revealed to the philosopher 150 years ago. The contradictory nature of Yelets' everyday life, the bizarre combinations of "high" and "low" for Rozanov "acquired a vital meaning there" [14: 35]. It is no coincidence that the philosopher's Yelets is viewed through the optics of a moral homeland. Rozanov's Yelets text is synchronized with the more authoritative text of Russian culture, which experienced at the turn of the 19th-20th centuries undoubted prosperity, as well as "spiritual ambiguity, confusion, a time of spiritual crisis, the tragic result of which was the fatal unpreparedness of the Russian cultural consciousness for the already nationwide crisis, for the revolutionary explosion of Russia itself" [15: 178]. 
In addition to the intellectual temptations of new readings of Rozanov's texts, this form of academic dialogue, taken outside the framework of the university audience, solves another problem. We are talking about new aesthetic horizons of the familiar ethnic landscape. Yelets expands and becomes deeper, and Rozanov's Yelets text is linked with Russian and world culture. Such an experience of comprehending this text can provoke future researchers to search for new subjects in the works of famous fellow countrymen.

\section{References}

1. G. Gachev, Natsionalnye obrazy mira. Kurs lektsii [National images of the world. A lecture course] (Akademiya, Moscow, 1998)

2. A.L. Panishchev, Voprosy kulturologii, 6, 60-65 (2020). https://doi.org/10.33920/nik01-2006-08

3. J. Le Goff, Intellektualy v srednie veka [Les intellectuels au Moyen Âge] (Izdatelstvo S-Peterburgskogo universiteta, Saint Petersburg, 2003)

4. V.V. Rozanov, Uedinennoe [Solitaria] (Politizdat, Moscow, 1990)

5. A.V. Skiperskikh, Obrazy bunta v tvorchestve V. Rozanova i M. Prishvina: Eletskii tekst [The images of riot in the works of V. Rozanov and M. Prishvin: Yelets text], in O.A. Dovgopolova and A.A. Kamenskikh (Eds.), Gumanitarnaya nauka v Rossii: ekzistentsialnoe izmerenie [The humanities in Russia: an existential dimension], 10-21 (Aleteiya, Saint Petersburg, 2017)

6. A.Yu. Klokov, A.A. Naidenov, A.V. Novoseltsev, Khramy i monastyri Lipetskoi i Eletskoi eparkhii [Temples and monasteries of Lipetsk and Yeletsk episcopates] (Lipetskoe oblastnoe kraevedcheskoe obshchestvo, Lipetsk, 2006)

7. V. Gorlov, Krasnoe znamya, May 4 (2006)

8. F. Rudnev, Podem, 5, 137-140 (1970)

9. V.V. Rozanov, Polnoe sobranie "Opavshikh Listev" [The complete collection of "Fallen Leaves"], Book 2: Smertnoe [Mortal Things] (Russkii put, Moscow, 2004)

10. A.V. Dmitriev, "Ya vyros sredi naroda...". Lipetskii krai v zhizni i tvorchestve I.A. Bunina ["I grew up among the people ...". The Lipetsk Territory in the life and work of I.A. Bunin] (Orius, Lipetsk, 2007)

11. Ru_Monumemt. Rozanov v Eltse [Rozanov in Yelets] (2009). Accessed on: November 03, 2020. [Online]. Available: https://ru-monument.livejournal.com/397086.html

12. V.A. Smyshlyaev, I.I. Yaresko, Sovremennaya ekonomika: problemy i resheniya, 10(118), 130-138 (2019). https://doi.org/10.17308/meps.2019.10/2232

13. V. Turbin, Smena, 11, 128-146 (1990)

14. G.P. Klimova, Dialektika eletskogo bytiya v zhizni i tvorchestve V.V. Rozanova [Dialectics of Yelets being in the life and work of V.V. Rozanova], in Rozanovskie chteniya. Materialy k respublikanskoi nauchnoi konferentsii [The Rozanov readings. Materials for the republican scientific conference], 33-35 (Eletskii gosudarstvennyi pedagogicheskii universitet, Elets, 1993)

15. A. Shmeman, Osnovy russkoi kultury. Besedy na Radio Svoboda. 1970-1971 [Foundations of Russian culture. Conversations on Radio Liberty in 1970-1971] (Izdatelstvo Pravoslavnogo Svyato-Tikhonovskogo gumanitarnogo universiteta, Moscow, 2017) 